\title{
NATURAL HISTORY NOTE \\ First record of Myotis crypticus (Ruedi, Ibanez, Salicini, Juste and Puechmaille, 2019) for Portugal
}

\author{
Zeltia López Gallego ${ }^{1}$, Virgínia Duro ${ }^{3}$, Ledicia Santos Fernández ${ }^{1}$, Gabriel Dasilva², Tamara Casal ${ }^{1}$, \\ Paulo Barros ${ }^{3^{*}}$
}

\author{
${ }^{1}$ Morcegos de Galicia - DROSERA, \\ Magdalena G-2, 20 izq, 15320 As Pontes \\ (A Coruña), Spain \\ ${ }^{2}$ CPI Uxío Novoneira. Ctra. Cervantes, $\mathrm{s} / \mathrm{n}$ \\ - 27670 - Pedrafita do Cebreiro (Lugo), \\ Spain \\ ${ }^{3}$ Laboratório de Ecologia Aplicada, \\ University of Trás-os-Montes e Alto \\ Douro, Vila Real, Portugal \\ *Corresponding author: \\ pbarros@utad.pt
}

\begin{abstract}
Myotis crypticus is a recently described bat species belonging to the Myotis nattereri species complex. Its distribution range is not entirely known and so far has only been found across Italy, southern France, and central and northern Spain. Here we present the first record of M. crypticus for Portugal. In October 2018, one individual of this species was captured at a swarming site within the Natura 2000 Site of Community Importance (SCl) Alvão/Marão in northern Portugal. The morphological identification of the bat in the field was later confirmed molecularly.
\end{abstract}

DOI: https://doi.org/10.14709/BarbJ.13.1.2020.05

Keywords: cryptic species, first record, Myotis crypticus, Portugal.

received: October, 31st 2019

accepted: April, 9th 2019

The Natterer's bat, Myotis nattereri, was supposed to be a morphologically uniform taxonomic entity and widespread across most of the Western Palearctic (Ruedi et al. 2019). However, molecular research carried out over the last few years has revealed that this species is a complex of several lineages considered as unnamed cryptic species (Ibáñez et al. 2006, Salicini et al. 2011, Puechmaille et al. 2012, Çoraman et al. 2019). As a result, the existence of two different species has been recently confirmed for the Iberian Peninsula (Juste et al. 2019): Myotis escalerai, which is mainly endemic to the Iberian Peninsula (Spain and Portugal), the Balearic Islands, and reaching the eastern French Pyrenees, and Myotis crypticus, which is found across Italy, southern France, and the north of Spain (Salicini et al. 2011), however the limits of its distribution, particularly in the north, are still unclear (Juste et al. 2019).

Our bat record was collected as part of a long-term bat mist-netting survey in the north of Portugal. During the mating season (September and October), we regularly monitor a swarming site located within the Natura 2000 Site of Community Importance (SCI) Alvão/Marão. This site is classified in the scope of the Natura 2000 network achieving the favourable conservation status of Mediterranean habitats and species of community importance. This site comprises approximately 58,788 ha and includes two distinct zones: the highlands (Marão: 1,416 m a.s.l. and Alvão: 1,330 $\mathrm{m}$ a.s.l.) localized between the Lamas de Olo plateau and the lowlands (Ermelo, Fervença and Régua, near the Douro river) where the lowest point of the $\mathrm{SCl}$ is located at $50 \mathrm{~m}$ a.s.I.. The Alvão/Marão site is located in an intermediate zone influenced by the Atlantic and the Mediterranean climates, which gives rise to a large diversity of habitats. Oak forests of the species Quercus pyrenaica and Quercus robur are predominant although agricultural areas (mainly pastures) can also be found. The $\mathrm{SCl}$ also encompasses an extended hydrologic network, characteristic of montane areas (Moreira et al. 2008), that offers favourable conditions to a high percentage of Portugal's inland bat community: supporting at least 22 of the 25 species known to occur in the country (Barros et al. 2012, Rainho et al. 2013).

Bats were captured at the swarming site using $2.5 \times 3 \mathrm{~m}$ and 2.5 x 9 m mist-nets (16x16 mm, 70/2 Nylon: Ecotone, Poland) and a harp trap (Bat Conservation and Management, EUA) placed at the caves' entrances or in the immediate surroundings.

The nets were opened one hour after sunset and kept open for five hours. Forearm length and body mass of each bat captured was measured using digital callipers ( \pm 0.01 $\mathrm{mm}$ ) and a digital scale $( \pm 0.01 \mathrm{~g})$. Reproductive status was checked according to Haarsma (2008). Bats belonging to a cryptic complex or a species of particular interest (e.g. $M$. escalerai/M. crypticus, Plecotus auritus/Plecotus austriacus, Myotis daubetonii) were subject to a skin biopsy sampling using a sterile puncher of a $3 \mathrm{~mm}$ diameter from the wing membrane (mesopatagium) (Ibáñez et al. 2006). Samples 


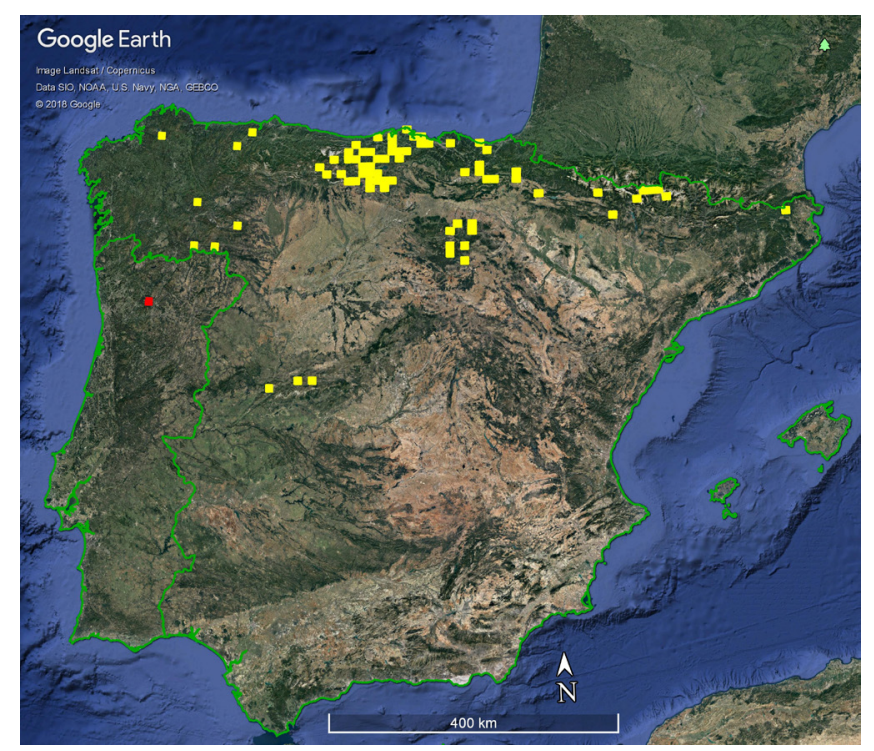

Fig. 1 - First record of Myotis crypticus for Portugal (red square), distribution of Myotis crypticus in Spain (yellow squares) (Salicini et al. 2013, Lorenzo et al. 2018, Molleda \& Fombellida 2018, Razgour et al. 2019).

were stored in sterile tubes containing $70 \%$ ethanol for subsequent molecular analysis. Bats were then released at the same capture site. Samples were sent for DNA analyses to the Laboratory of Molecular Ecology (LEM) at the Estación Biológica de Doñana (EBD-CSIC) in Seville, Spain.

In the laboratory, DNA was extracted from the wing biopsies following Higuchi et al. (1988). A fragment of subunit 1 of the mitochondrial $\mathrm{NADH}$ dehydrogenase (ND1) gene was amplified using primers ND1-F2 and ND1-R (Kawai et al. 2002). The PCR mix (20 $\mu$ l final reaction volume) included $2 \mu \mathrm{l}$ of DNA extract, $1 \mu \mathrm{l}$ of each primer (10 mM), $0.8 \mu \mathrm{l}$ of $\mathrm{MgCl} 2(50 \mathrm{mM}), 0.16 \mu \mathrm{lNTP}(25 \mathrm{mM})$, 0.5 unit of taq-polymerase with appropriate buffer and $\mathrm{H}_{2} \mathrm{O}$. Thermocycling consisted of $5^{\prime}$ initial denaturation at $94^{\circ} \mathrm{C}$, followed by 40 cycles at $94^{\circ} \mathrm{C}\left(30^{\prime \prime}\right), 52^{\circ} \mathrm{C}\left(30^{\prime \prime}\right)$ and $72^{\circ} \mathrm{C}$ $\left(1^{\prime} 30^{\prime \prime}\right)$, with a final extension at $72^{\circ} \mathrm{C}\left(5^{\prime}\right)$. The fragment was sequenced directly from purified PCR product using an $A B I$ 3,100 automated sequencer (Applied Biosystems, Warrington, UK), following the manufacturer's protocols. The partial sequences were aligned and edited using the program Geneious R7 (Biomatters Ltd.) and visually inspected. For species identification purposes, the obtained sequences were compared to available sequences in the GenBank database (http://www.ncbi.nlm.nih.gov/GenBank) using the BLAST tool.

On October $12^{\text {th }} 2018$ in a swarming site at the $\mathrm{SCl}$ Alvão/Marão (UTM WGS84 NF97; elevation: 760 m a.s.I.) (Fig. 1), one male belonging to the species M. crypticus was caught (Fig. 2). The individual was measured (FA $=37.44$ $\mathrm{mm})$, weighed ( $\mathrm{W}=5.50 \mathrm{~g}$ ) and its reproductive status was checked, showing signs of sexual maturity (epididymis appeared swollen and black). During the same survey, we also caught $42 \mathrm{M}$. escalerai (the other species of the Natterer's cryptic species complex present in Portugal) and further nine species (Myotis myotis, Myotis blythii, Myotis bechsteinii, Myotis emarginatus, M. daubentonii, P. auritus, $P$. austriacus, Rhinolophus ferrumequinum and Rhinolophus hipposideros).

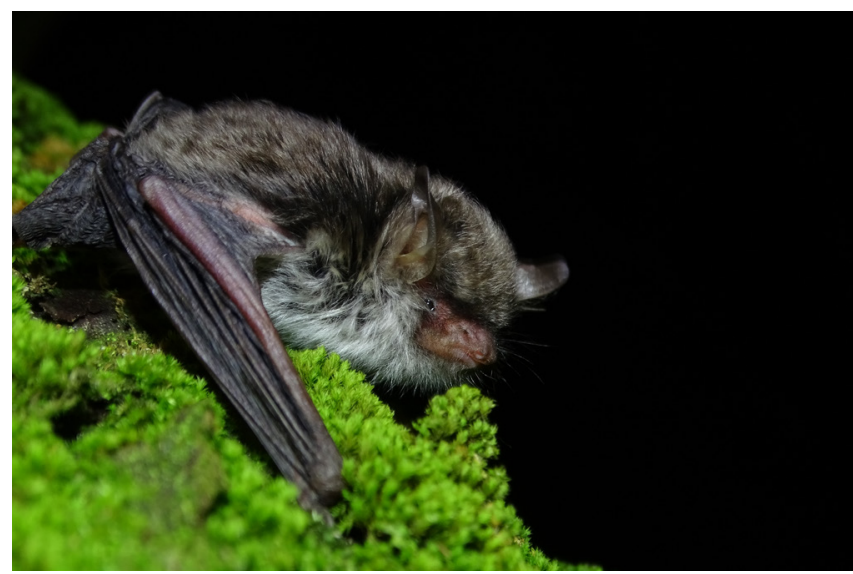

Fig. 2 - Individual of Myotis crypticus (@ Paulo Barros).

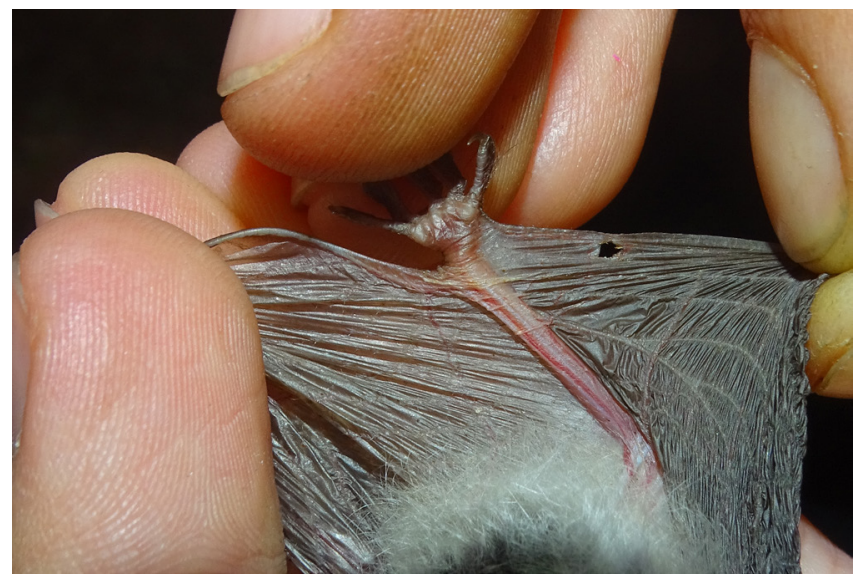

Fig. 3 - Ventral views of the insertion of the plagiopatagium at the base of the toe in the Myotis crypticus captured (C Paulo Barros).



Fig. 4 - Ventral views of fringing stiff hairs directed outwards present along the tail membrane in the Myotis crypticus captured (C) Paulo Barros).

The species $M$. crypticus was morphologically distinguished from the $M$. escalerai by the observation of the wing membrane insertion at the base of the toe (Fig. 3 ) and the stiff hairs along the uropatagium margin (Fig. 4). Molecular analysis of the sample collected allowed the unequivocal taxonomic confirmation of the identification carried out in the field. The sequence of around $950 \mathrm{bp}$ of the ND1 fragment showed > 95\% identity with available homologous ND1 sequences of $M$. crypticus in GenBank in a BLAST comparison, confirming unambiguously that the small Myotis was the recently described M. crypticus (GenBank accession number:MT090964). 
Around the roost where M. crypticus was first found in Spain (Cueva Cerraúco, El Rasillo de Cameros, La Rioja [ca. $42^{\circ} 11^{\prime} 0^{\prime \prime} \mathrm{N}, 2^{\circ} 44^{\prime} 20^{\prime \prime} \mathrm{W}$ ], 1,400 $\mathrm{m}$ a.s.l.) the species is commonly found in dense forests of Pyrenean oak $(Q$. pyrenaica) and beech (Fagus sylvatica), in forests cleared for pasture but which retain scattered old-growth trees and also in subalpine prairies up to 2,000 m a.s.l. (Juste et al. 2019). The swarming site where we caught the individual of $M$. crypticus is surrounded by goat grazing pastures composed of Ericaceae shrubs with sparse pines (Pinus sylvestris and Pinus pinaster). Adjacent areas are predominantly composed of broadleaf woodland $(Q$. pyrenaica, $Q$. robur and Castanea sativa) and agricultural land. Therefore, our record (considering the surrounding habitat and elevation of $760 \mathrm{~m}$ a.s.l.), is in keeping with the ecological requirements observed in other studies and localities, including Western Switzerland (Beck 1991, Arlettaz 1996) , France (Puechmaille et al. 2012) and Italy (Salicini et al. 2013).

The adult male of $M$. crypticus found at the swarming site showed evidence of sexual maturity and was swarming together with ten other bat species, including the sibling $M$. escalerai. A similar pattern was described in other studies, mainly in Switzerland, France, Italy, and Spain, where $M$. crypticus has been observed gathering in large numbers with other Myotis species at swarming sites in autumn (Juste et al. 2019).

The lack of knowledge about the distribution, behaviour and ecology of $M$. crypticus stems from its recent recognition as a separate species. Therefore specific studies concerning its ecology and the potential interactions between this species and $M$. escalerai are yet to be conducted (Juste et al. 2019). The recent recognition of $M$. crypticus as an independent species results in the need to evaluate its population's status and distribution under the criteria of the IUCN (Juste et al. 2019) and for the inclusion of this new species in the Portuguese Red Data Book for Vertebrates to receive appropriate protection.

\section{ACKNOWLEDGEMENTS}

Fieldwork was conducted under license from the Institute of Nature Conservation and Forestry (39/2018/ CAPT). The authors are grateful to Javier Juste and staff form the Laboratorio de Ecología Molecular (LEM) of Estación Biológica de Doñana (CSIC), for performing the molecular taxonomic identification. We are grateful to the two anonymous reviewers for their constructive suggestions, which helped us to improve the manuscript during the peerrevision process.

\section{Conflict of interests}

The authors declare that they have no conflict of interest.

\section{REFERENCES}

ARLETTAZ, R. (1996). Foraging behaviour of the gleaning bat Myotis nattereri (Chiroptera, Vespertilionidae) in the Swiss Alps. Mammalia, 60(2): 181-186. https://doi. org/10.1515/mamm.1996.60.2.181
BARROS, P. (2012). Contribución al conocimiento de la distribución de quirópteros en el norte y centro de Portugal. Barbastella, 5(1): 19-31.https://doi. org/10.14709/BarbJ.5.1.2012.04

BECK, A. (1991). Nahrungsuntersuchungen bei der Fransenfledermaus, Myotis nattereri (Kuhl, 1818). Myotis, 29: 67-70.

ÇORAMAN, E., DIETZ, C., HEMPEL, E., GHAZARYAN, A., LEVIN, E., PRESETNIK, P., ZAGMAJSTER, M. \& MAYER, F. (2019). Reticulate evolutionary history of a Western Palaearctic bat complex explained by multiple mtDNA introgressions in secondary contacts. J Biogeogr, 46(2): 343-354.https://doi.org/10.1111/jbi.13509

HAARSMA, A. -J. (2008). Manual for assessment of reproductive status, age and health in European Vespertilionid bats. Electronic publication, version 2. ed.: Zoogdiervereniging. Arnhem, Netherlands.

HIGUCHI, R., KRUMMEL, B. \& SAIKI, R. K. (1988). A general method of in vitro preparation and specific mutagenesis of DNA fragments: study of protein and DNA interactions. Nucleic Acids Research, 16(15): 7351-7367. https://doi. org/10.1093/nar/16.15.7351

IBÁÑEZ, C., GARCÍA-MUDARRA, J. L., RUEDI, M., STADELMANN, B. \& JUSTE, J. (2006). The Iberian contribution to cryptic diversity in European bats. Acta Chiropterologica, 8(2): 277-297. https://doi. org/10.3161/150811006779398582

JUSTE, J., RUEDI, M., PUECHMAILLE, S. J., SALICINI, I. \& IBÁÑEZ, C. (2019). Two new cryptic bat species within the Myotis nattereri species complex (Vespertilionidae, Chiroptera) from the Western Palaearctic. Acta Chiropterologica, 20(2): 285-300. https://doi.org/10.316 1/15081109ACC2018.20.2.001

KAWAI, K., NIKAIDO, M., HARADA, M., MATSUMURA, S., LIN, L. -K., WU, Y., HASEGAWA, M. \& OKADA, N. (2002). Intraand interfamily relationships of Vespertilionidae inferred by various molecular markers including SINE insertion data. J Mol Evol, 55: 284-301. https://doi.org/10.1007/ s00239-002-2326-0

LORENZO, R. J. H., FERNÁNDEZ, L. S. \& GALLEGO, Z. L. (2018). Contribución al conocimiento de la distribución y ecología de los murciélagos (Orden Chiroptera) en Castilla y León. Journal of Bat Research \& Conservation, 11(1).https://doi.org/10.14709/BarbJ.11.1.2018.08

MOLLEDA, R. \& FOMBELLIDA, I. (2018). Contribución al conocimiento de la distribución y estatus de la fauna quiropterológica de la Comunidad Autónoma de Cantabria. Journal of Bat Research \& Conservation, 11(1). https://doi.org/10.14709/BarbJ.11.1.2018.04

MOREIRA, P., ARNALDO, P. \& BARROS, P. (2008). Odonata records from Natura 2000 network site Alvão-Marão (Portugal). Boletín Sociedad Entomológica Aragonesa, 43: 395-398. 
PUECHMAILLE, S. J., ALLEGRINI, B., BOSTON, E. S. M., DUBOURG-SAVAGE, M. -J., EVIN, A., KNOCHEL, A., LE BRIS, Y., LECOQ, V., LEMAIRE, M., RIST, D. et al. (2012). Genetic analyses reveal further cryptic lineages within the Myotis nattereri species complex. Mammalian Biology, 77(3): 224-228.https://doi.org/10.1016/j. mambio.2011.11.004

RAINHO, A., ALVES, P., AMORIM, F. \& MARQUES, J. T. (2013). Atlas dos morcegos: de Portugal continental. ed.: Instituto da Conservação da Natureza e das Florestas. Agualva-Cacém, Portugal, 100 pp.

RAZGOUR, O., FORESTER, B., TAGGART, J. B., BEKAERT, M., JUSTE, J., IBÁÑEZ, C., PUECHMAILLE, S. J., NOVELLAFERNANDEZ, R., ALBERDI, A. \& MANEL, S. (2019). Considering adaptive genetic variation in climate change vulnerability assessment reduces species range loss projections. Proceedings of the National Academy of Sciences, 116(21): 10418-10423. https://doi. org/10.1073/pnas.1820663116
RUEDI, M., PUECHMAILLE, S. J., IBÁÑEZ, C. \& JUSTE, J. (2019). Unavailable names in the Myotis nattereri species complex. J Biogeogr, 46(9): 2145-2146. https:// doi.org/10.1111/jbi.13665

SALICINI, I., IBÁÑEZ, C. \& JUSTE, J. (2011). Multilocus phylogeny and species delimitation within the Natterer's bat species complex in the Western Palearctic. Molecular Phylogenetics and Evolution, 61(3): 888-898. https://doi. org/10.1016/j.ympev.2011.08.010

SALICINI, I., IBÁÑEZ, C. \& JUSTE, J. (2013). Deep differentiation between and within Mediterranean glacial refugia in a flying mammal, the Myotis nattereri bat complex. J Biogeogr, 40(6):1182-1193. https://doi.org/10.1111/ jbi.12062 